\title{
Die
}

\section{Londoner Polizeigerichte.}

Von

\section{Dr. Walther Seelmann,}

Amtsrichter in Stettin.

(Sonderabdruck aus den Mitteilungen der Internationalen Kriminalistischen Vereinigung, Band XIX Heft 1.)

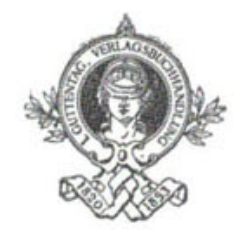

BERLIN 1912.

J. Guttentag, Verlagsbuchhandlung,

G. m. b. H. 
